\title{
Capital Control, Financial Depth and the Demand of Foreign Reserves: Evidence on 1994-2013 Data in China
}

\author{
Dianlei Lu, Zhixin Liu \\ School of Economics and Management, Beihang University, Beijing, China \\ Email: Idlholmes@163.com
}

Received April 2014

\begin{abstract}
We combined foreign reserves, capital control and financial depth with other economic variables in the same model and discussed the factors that affect the demand of China's foreign reserves. The results showed that 1) a considerable number of foreign reserves are passively accumulated, for instance, stronger capital controls deeper financial system will lower the demand of foreign reserves; 2) the ratio of Hot Money/GDP is more significant than the FDI/GDP as a proxy of foreign reserves' protective demand.
\end{abstract}

Keywords

Foreign Reserves, Capital Controls, Financial Depth

\section{Introduction}

At the end of 2013, China held a huge stock of international reserves at the amount of US\$ 3821.3 billion foreign exchange reserves, which is far more enough to prevent financial risks. Most research about China's foreign exchange reserves are basically admitted that international capital could flow in and out of China with few restrictions. However, the capital controls are not under consideration, which probably cause miscalculation on the optimal quantity and the opportunity cost of foreign exchange reserves. Therefore, this paper will show significance theoretically and practically by integrating capital controls and other variables to re-estimate the foreign exchange reverses demand model.

\section{Literature Review}

The earlier empirical studies measured the demand of foreign exchange reserves through various ratios, such as reserves to import [1]; or the cost and return of reserves [2]. Frenkel (1980) [3] suggested that the model of monetary demand should be established to define the optimal foreign exchange reserves. There are also some recent researches that resubmit the motive of Mercantilism [4] and precaution [5].

Several Chinese studies investigated the China's demand of foreign exchange reserves on various periods and their conclusions are as follows: (1) believing that the demand had already exceeded the optimal quantity or 
zone [6] [7]; (2) that the quantity was still in the optimal zone [8]; (3) that China had insufficient quantity of foreign exchange reserves [9]. And there are some different points of this issue made by other researchers.

In spite of these fruitful studies, international and domestic, there are still some obvious shortcomings: (1) most studies presumed that the international capital can flow in and out of China freely, without consideration of the existence of capital controls, which, when works efficiently, can on some level could maintain the economy steadily and consequently reduce the actual demand of foreign exchange reserves. (2) During the period, substantially speculative capital, as known as Hot Money, flew in China and away after making a huge profit from the appreciation of RenMinBi, which will cause the economic turmoil. So the effect of Hot money should also be considered in the model of foreign exchange reserves.

\section{Reserve Demand Function}

Most researches divided the demand of foreign exchange reserves into three levels: transactional requirement (R_1), precautionary requirement (R_2) and speculative requirement (R_3). However, apart from these requirements, the effect of capital controls and hot money should also be under consideration. Therefore, we establish this model as follows:

$$
R E S=R_{1}+R_{2}+R_{3}+\sum P
$$

Firstly, to cover the transactional requirement, we use the proxy of average propensity to import (API). The more the average propensity to import is, the bigger the effect suffered from outer shocks, therefore the more reserve holdings will be needed. As the proxy of economic opening, the coefficient of API should be positive.

Secondly, with the prosperity of Chinese economy, numerous international capitals enter into China by all kinds of investment; some of these are speculative capitals, also as known as Hot Money, which could cause turmoil by sudden flew. Thus the sufficient reserve holdings should be kept for precautionary demand. Some studies calculated Hot Money by Balance of Payment (BOP), that Hot Money equals to the newly added foreign exchange reserves minus FDI and Trade Balance [10], yet this measurement not only ignored the effect caused by the change of exchange rate and returns of foreign exchange reserves, but also presumed that no Hot Money in FDI. This paper will use a new approach which can avoid those problems above. We estimate that Hot Money should equal to the Newly Added Funds outstanding for foreign exchange minus the actual utilization of foreign capital and trade balance. Hot Money/GDP should have a positive relation with foreign exchange reserve holding for precautionary reason. We also use FDI/GDP as an alternative variable. Because the large amount of FDI returns come back to the mother countries will reduce foreign exchange reserves.

Thirdly, many recent studies have blamed the short-term external debt (STED) as one of the reasons for financial crises (see [11] [12]). More importantly, the STED is considered to be an important indicator to measure the foreign exchange reserves by the People's Bank of India (PBC). At the end of 2013, the accumulative STED reached to more than $\$ 640$ billion, as many as $7 \%$ of GDP or $70 \%$ of total external debt. A large of reserves will be used to pay back. Therefore, we include the relative size of STED (ratio of STED/GDP) in the reserve demand function.

Fourthly, most papers on reserves demand are presumed the free floating system (see [13]-[16]). However, China has restrictions about international capitals; therefore some proper variables should be adopted for describing this kind of effect, such as the differential between international and domestic interest rate $(\Delta R)$ and the expected volatility of RMB exchange rate (EXVOL). Wang \& He (2007) [17] proved that there are longterm relations among short-term capital inflow and, EXVOL. Bai \& Wang (2008) [18] also use the differential of interest rate to discuss the efficiency of capital controls under the framework of Interest Rate Parity Theory. The more effective the capital controls, the less influential the financial turmoil caused by capital inflow and outflow, which will decrease the demand of reserve holding. Therefore, the coefficient of and EXVOL should be negative.

Fifthly, we also use a new variable to keep the financial depth into consideration. When comes to financial depth and development, M2/GDP is commonly used by literatures, e.g. [19]-[21], etc. But simply using that proxy cannot reflect the degree of China's financial depth correctly, as Edwards (1996) [22] pointed out that "under an immature market with restrictions on borrowing and lending money, there is always a negative trend between them (financial depth and M2/GDP)". Thus we will use another variable to represent the financial depth of China, Funds outstanding for Foreign exchange (FOFX)/GDP. On the one hand, over this period, 20\% to 60\% 
of monetary supply was contributed by FOFX, which shows some passiveness on monetary policy and imperfection of financial development; on the other hand, the variation of this ratio also reflected whether the central bank has enough financial instruments and assets to neutralize the excess FOFX. Compared with M2/GDP, FOFX/GDP will be more appropriate as a proxy of China's financial depth. The bigger the ratio, the more superficial the financial depth, and will need more reserves. Thus, the coefficient should be positive.

Sixthly, to satisfy the speculative demand of foreign exchange reserves, there will be opportunity cost (OC) for this session of reserve holding. Therefore we can use OC to measure the speculative demand of reserves, namely the differentials between 3-month Treasury Bill Rate and China's 3-month Redemption Rate. And a negative relation between $\mathrm{OC}$ and reserve holding demand are expected.

Then we establish the model as follows,

$$
\begin{aligned}
& R E S=\gamma_{0}+\gamma_{1} O C_{t-1}+\gamma_{2} \mathrm{HM}_{t-1}+\gamma_{3} \mathrm{EXVOL}_{t}+\gamma_{4} \mathrm{FOFX}_{t-1}+\gamma_{5} \Delta R_{t-2} \\
& +\gamma_{6} S T E D_{t-1}+\gamma_{7} A P I_{t-2}+\gamma_{8} F D I_{t}+\varepsilon_{t}
\end{aligned}
$$

which RES means the ratio between the newly added reserves and GDP, OC is the differentials between 3-month Treasury Bill Rate and China's 3-month Redemption Rate, HM is Hot Money/GDP, EXVOL is the expected volatility of RMB exchange rate, FOFX is the ratio of FOFX and GDP, is the differential between benchmark interest rate of China' monetary market and US\$ LIBOR, STED is STED/GDP, API is the amount of import/GDP, FDI is FDI/GDP. We will use logarithm value on, EXVOL, STED and FDI.

\section{Empirical Results}

The data used in this study are quarterly observations and the sample period spans from 1997: 01 to 2013: 04 base on the data's availability. All data are openly published by People's Bank of China, Ministry of Commerce of PRC, General Administration of Customs, National Bureau of Statistics, State Administration of Foreign Exchange and Federal Reserve Bank of ST. Louis, USA.

We consider two traditional unit root tests, which are augmented Dickey-Fuller test (ADF) and Phillips-Perron test (PP), to confirm the stationary of variables. The result of unit root tests is presented in Table 1. All variables included in the model are found to be integrated of order one, i.e. I(1).

Given that variables are non-stationary, it is not justified to estimate the reserve demand function using OLSs because the results might be spurious. Therefore, we apply the cointegration test developed by Johansen (1988) [23] to investigate the presence of long-run relation among variables. The results of Johansen cointegration (Table 2) show that the null hypothesis of no cointegration is strongly rejected in favor of one cointegrating relation with plausible (normalized) coefficients. This implies that all variables share a common stochastic trend and do move together in the long-run.

Based on the estimated normalized cointegrating vector, the long-run relationship between foreign exchange reserves and its determinants is expressed below Table 3.

The results of regression showed that: 1) despite the conventional model or the new model, with introduction of the factors of capital controls and financial depth, the R-squared, Adjusted R-squared and F-statistic are significantly improved, which means the explanation of the model is better; 2) the coefficient of HM/GDP is more significant than that of FDI/GDP and the new model is superior to the conventional one, which mean that

Table 1. Results of unit root test.

\begin{tabular}{cccccccccc}
\hline At level & RES & OC & HM & EXVOL & FOFX & $\Delta$ R & STED & API & FDI \\
\hline ADF & $-0.36^{*}$ & -2.45 & -0.25 & -3.3 & 0.42 & -1.63 & -1.91 & $-3.55^{*}$ & -1.31 \\
PP & -4.47 & -2.52 & -1.29 & -2.54 & -0.67 & -1.62 & -1.91 & $-3.55^{*}$ & -2.88 \\
At $1^{\text {st }}$ difference & dRES & dOC & dHM & dEXVOL & dFOFX & d $\Delta$ R & dSTED & dAPI & dFDI \\
ADF & $-11.74^{* * *}$ & $-2.84^{* * *}$ & $-5.63^{* * *}$ & $-4.32^{* * *}$ & $-4.56^{* * *}$ & $-3.47^{* * *}$ & $-4.08^{* * *}$ & $-7.08^{* * *}-4.70^{* * *}$ \\
PP & $-10.38^{* * *}$ & $-2.85^{* * *}$ & $-5.24^{* * *}$ & $-4.33^{* * *}$ & $-3.93^{* * *}$ & $-3.39^{* * *}$ & $-4.11^{* * *}$ & $-6.36^{* * *}$ & $-2.82^{* * *}$ \\
\hline
\end{tabular}

Note: (1) Optimal lags for ADF is determined based on AIC and for PP test it is Newey-West bandwidth selection using Bartlett kernel. (2) Probability values for ADF and PP test is as per MacKinnon one-sided p-values. "Indicates significant at $10 \%$ critical level. ${ }^{* *}$ Indicates significant at $5 \%$ critical level. ${ }^{* * *}$ Indicates significant at $1 \%$ critical level. 
Table 2. Results of Johansen cointegration test: reserve demand function.

\begin{tabular}{cccccc}
\hline & Trace Test & & \multicolumn{3}{c}{ Max-eigenvalue test } \\
\hline Rank & Eigenvalue & Trace-Stat. & Rank & Eigenvalue & Max-stat. \\
\hline None & 0.896039 & $182.8032^{* *}$ & None & 0.896039 & $87.6838^{* *}$ \\
At most 1 & 0.738574 & $105.3975^{* *}$ & At most 1 & 0.738574 & $65.5478^{* *}$ \\
At most 2 & 0.547406 & 62.7138 & At most 2 & 0.547406 & 49.13162 \\
At most 3 & 0.424308 & 51.1889 & At most 3 & 0.424308 & 37.32434 \\
At most 4 & 0.375070 & 40.64101 & At most 4 & 0.375070 & 23.50677 \\
At most 5 & 0.281482 & 37.13424 & At most 5 & 0.281482 & 19.36261 \\
At most 6 & 0.220867 & 29.96095 & At most 6 & 0.220867 & 10.14829 \\
\hline
\end{tabular}

Note: (1) VAR specification: optimal lag length selected using AIC, (2) deterministic trend assumptions of the cointegration test: intercept and trend in cointegrating relationship and no trend in VAR. ${ }^{*}$ Indicates significant at $10 \%$ critical value. ${ }^{* *}$ Indicates significant at $5 \%$ critical value.

Table 3. The comparison of results.

\begin{tabular}{|c|c|c|c|c|}
\hline & Conventional model & $\begin{array}{l}\text { Conventional model } \\
\text { with cc, } \mathrm{fd}\end{array}$ & New model & New model with cc, fd \\
\hline $\begin{array}{l}\text { Hot Money/GDP } \\
\qquad(\mathrm{HM})\end{array}$ & & & $\begin{array}{l}0.177^{* * *} \\
(0.039) \\
{[4.575]}\end{array}$ & $\begin{array}{l}0.046^{* * *} \\
(0.012) \\
{[3.757]}\end{array}$ \\
\hline FDI/GDP & $\begin{array}{c}0.007 \\
(0.046) \\
{[0.146]}\end{array}$ & $\begin{array}{c}0.012 \\
(0.017) \\
{[0.7]}\end{array}$ & & \\
\hline $\begin{array}{l}\text { Opportunity Cost } \\
\text { (OC) }\end{array}$ & $\begin{array}{c}-0.864^{* *} \\
(0.288) \\
{[-2.997]}\end{array}$ & $\begin{array}{c}-0.734^{* * *} \\
(0.157) \\
{[-4.672]}\end{array}$ & $\begin{array}{c}-0.513^{*} \\
(0.244) \\
{[-2.102]}\end{array}$ & $\begin{array}{c}-0.724^{* * *} \\
(0.076) \\
{[-9.503]}\end{array}$ \\
\hline $\begin{array}{l}\text { Short-Term Debt Ratio } \\
\text { (STED) }\end{array}$ & $\begin{array}{l}0.044^{* * *} \\
(0.012) \\
{[3.669]}\end{array}$ & $\begin{array}{l}0.02^{* *} \\
(0.007) \\
{[2.844]}\end{array}$ & $\begin{array}{l}0.027^{*} \\
(0.014) \\
{[1.913]}\end{array}$ & $\begin{array}{l}0.009^{*} \\
(0.004) \\
{[2.119]}\end{array}$ \\
\hline $\begin{array}{l}\text { Average Propensity to Import } \\
\text { (API) }\end{array}$ & $\begin{array}{c}1.142 \\
(0.739) \\
{[1.546]}\end{array}$ & $\begin{array}{c}0.02 \\
(0.396) \\
{[0.151]}\end{array}$ & $\begin{array}{l}1.422^{* *} \\
(0.502) \\
{[2.831]}\end{array}$ & $\begin{array}{c}0.595^{* *} \\
(0.19) \\
{[3.136]}\end{array}$ \\
\hline $\begin{array}{l}\text { Funds Outstanding for Foreign } \\
\text { Exchange } \\
\text { (FOFX) }\end{array}$ & & $\begin{array}{l}0.075^{* *} \\
(0.026) \\
{[2.848]}\end{array}$ & & $\begin{array}{l}0.747^{* * *} \\
(0.077) \\
{[9.658]}\end{array}$ \\
\hline $\begin{array}{l}\text { the Expected Volatility of RMB } \\
\text { Exchange Rate (EXVOL) }\end{array}$ & & $\begin{array}{l}0.007^{* *} \\
(0.002) \\
{[3.207]}\end{array}$ & & $\begin{array}{c}-0.006^{* * *} \\
(0.001) \\
{[-6.664]}\end{array}$ \\
\hline $\begin{array}{l}\text { the Differential of Interest Rate } \\
\qquad(\Delta \mathrm{R})\end{array}$ & & $\begin{array}{l}0.01^{* * *} \\
(0.002) \\
{[5.608]}\end{array}$ & & $\begin{array}{c}-0.008^{* * *} \\
(0.001) \\
{[-5.725]}\end{array}$ \\
\hline R-squared & 0.787 & 0.977 & 0.864 & 0.99 \\
\hline Adjusted R-squared & 0.654 & 0.95 & 0.804 & 0.978 \\
\hline Prob (F-statistic) & 0.014 & 0.000 & 0.003 & 0.000 \\
\hline
\end{tabular}

Note: cc and fd represent the factors of capital controls and financial depth separately; The figures in () are standard deviation and those in [] are t-statistics; ${ }^{*}$ Indicates significant at $10 \%$ critical level. ${ }^{* * *}$ Indicates significant at $5 \%$ critical level. ${ }^{* * * *}$ Indicates significant at $1 \%$ critical level. 
HM/GDP is more proper variable as an indicator for the productive demand of foreign reserves, 3) with the consideration of capital control and financial depth, the coefficients of demand in transaction, protection and speculation are, though still significantly, all witnessed huge drops by $60 \%, 70 \%$ and $40 \%$, separately. They illustrated that huge amount of foreign reserves are not only accumulated actively, but passively, because of the immature of financial system, especially the foreign exchange management. 4) and we found that the strict capital controls also cause passively accumulation of foreign reserves.

So the model of demand of foreign reserves is displayed as follows:

$$
\begin{aligned}
R E S=0.06-0.72 O C_{t}+0.05 H M_{t}-0.006 E X V O L_{t}+0.75 F O F X_{t} \\
-0.008 \Delta R_{t}+0.01 S T E D_{t}+0.6 A P I_{t}+\varepsilon_{t} \\
(3.298 * * *)(-9.50 * * *)(3.757 * * *) \\
(-6.664 * * *)(9.656 * * *) \\
(-5.725 * * *)(2.119 * *)(3.136 * * *)
\end{aligned}
$$

The results of the reserve demand function show that hot money, funds outstanding for foreign exchange, short-term external debt and average propensity to import are statistically significant and have positive impacts on the demand of foreign exchange reserves; yet the measure of the opportunity cost, exchange rate volatility and differentials between international and domestic interest rate is found to be negative and significant, which all agrees with a priori reasoning. All the estimated parameters, except foreign direct investment, are significant at the $5 \%$ level and signs of all the coefficients are consistent with the theoretical explanations. Further, our results also show that foreign direct investment is not an important determinant of reserve demand in China.

\section{Conclusions}

Firstly, this paper considered the issue of conventional measurement and 'internal drain' and used the yearly data from 2002 to 2013 to calculate China's adequate and excess foreign reserves, found that China held a lot of excess reserves and undertake considerable opportunity cost.

Secondly, we took capital controls and financial depth into consideration and renew the conventional model of foreign reserves demand, which caused the passive accumulation on foreign reserves demand.

Thirdly, compared to FDI/GDP, in the new model we noticed that HM/GDP is more significant and lead to a better outcome. In order to avoid the volatility caused by short-term speculative capital, HM/GDP is a more specific index to the protective demand of foreign reserves.

\section{References}

[1] Triffin, R. (1960) Gold and the Dollar Crisis. Yale University Press.

[2] Heller, H.R. (1966) Optimal International Reserves. Economics Journal, 76, 296-311. http://dx.doi.org/10.2307/2229716

[3] Frenkel, J. and Jovanocic, B. (1980) On the Transactions and Precautionary Demand for Money. Quarterly Journal of Economics, 90, 80-95

[4] Calvo, G.A. and Reinhart, C.M. (2002) Fear of Floating. The Quarterly Journal of Economics, 117, 379-408. http://dx.doi.org/10.1162/003355302753650274

[5] Fischer, S. (1999) On the Need for an International Lender of Last Resort. Journal of Economic Perspectives, 13, 85104. http://dx.doi.org/10.1257/jep.13.4.85

[6] Wang, Q.L. (2008) The Empirical Research on Optimal Scale of China's Foreign Exchange Reserves. Studies of International Finance, 9, 73-79. (in Chinese)

[7] Wang, L.Y. and Wang, K. (2010) Measurement of Optimal Foreign Exchange Reserve in China. Economic Review, 4, 117-123. (in Chinese)

[8] Ren, R.E. and Liu, L.Y. (2004) The Measurement and Analyze on Optimal Scale of China's Foreign Exchange Reserves. Finance \& Trade Economics, 5, 61-68. (in Chinese)

[9] Huang, J. (2002) The Dynamic Measurement on the Demand of Foreign Exchange Reserves. World Economic Forum, 6, 62-69. (in Chinese)

[10] Lu, J. and Luo, W.Q. (2010) The Measurement and Analyze on Monthly Hot Money. Statistics and Decision, 19, 85- 
89. (in Chinese)

[11] Furman, J. and Stiglitz, J. (1998) Economic Crises: Evidence and Insights from East, Asia. Brookings Papers on Economic Activity, 2, 1-114. http://dx.doi.org/10.2307/2534693

[12] Radelet, S. and Sachs, J. (1998) The East Asian Financial Crisis: Diagnosis, Remedies, Prospects. Brookings Papers on Economic Activity, 1, 1-74. http://dx.doi.org/10.2307/2534670

[13] Bird, G. and Rajan, R. (2003) Too Much of a Good Thing? The Adequacy of International Reserves in the Aftermath of Crises. The World Economy, 26, 873-891. http://dx.doi.org/10.1111/1467-9701.00552

[14] De Beaufort Wijnholds, J.A.H. and Kapteyn, A. (2001) Reserve Adequacy in Emerging Market Economies. Working Paper No. 01/43, IMF.

[15] Liu, L.Y. (2008) Did Hot Money Promote the Stock Market and Real Estate Market? Journal of Financial Research, 10, 48-70. (in Chinese)

[16] Sheng, L.G. and Zhao, H.Y. (2007) Yields and Currency Composition of Foreign Reserves and Hot Money in China. China Economic Quarterly, 6, 1255-1276. (in Chinese)

[17] Wang, S.H. and He, F. (2007) China's Short-Term International Capital Flows: Status, Pathways and Factors. The Journal of World Economy, 7, 12-19. (in Chinese)

[18] Bai, X.Y. and Wang, P.J. (2008) The Effectiveness of Capital Control and Reform of Exchange Rate Regimes in China. Journal of Quantitative \& Technical Economics, 9, 65-75. (in Chinese)

[19] McKinnon, R.I. (1989) Finance and Economic Development. Oxford Review of Economic Policy, Vol. 5, No. 1.

[20] Li, S.K. (2006) Foreign Exchange Reserves VS External Debt. Economic Herald, 10, 79-81. (in Chinese)

[21] Lin, Y.F., Zhang, Q. and Liu, M.X. (2003) Financial Structure and Economic Growth. The Journal of World Economy, 1, 3-21. (in Chinese)

[22] Edwards, S. (1996) Exchange Rates and the Political Economy of Macroeconomic Discipline. American Economic Review, 86, 159-163.

[23] Johansen, S. (1988) Statistical Analysis of Cointegration Vectors. Journal of Economic Dynamics and Control, 12, 231-254. http://dx.doi.org/10.1016/0165-1889(88)90041-3 